\title{
CURRENT STATUS AND BARRIERS TO FISHERIES CO-MANAGEMENT: EVIDENCES FROM AN OXBOW LAKE OF BANGLADESH
}

Md. Monirul Islam*, Chandan Kar, Goutam Kumar Kundu, Gouri Mondal and Mohammad Shahneawz Khan

Department of Fisheries, University of Dhaka, Dhaka-1000, Bangladesh

\begin{abstract}
Co-management of common property aquatic habitats are increasingly implemented with a view to increasing fish production, ensuring fishers' rights and to conserve biodiversity. This study investigates the current status and identifies barriers to fisheries management in an oxbow lake (baor) at Jessore district, Bangladesh. Using interviews, focus group discussions and secondary data, this study revealed that both capture and culture fisheries are practised at the same time at the same water-body. As the wetland was used solely for capture fisheries before, the introduction of aquaculture practice has increased the total fish production and income for some people. However, it has reduced the access to poor fishers and fish biodiversity. Particularly the biodiversity of Channa sp, Puntius sp, Mastacembelus sp, Mystus sp, and Colisa fasciatus has been reduced. A range of climatic, institutional, economic and social barriers have facilitated the reduced access of poor fishers and biodiversity. To overcome the barriers and ensure sustainable management of the baor this study proposes to implement a fair leasing system, increase financial and human resources together with an ecosystem-based approach to baor management.
\end{abstract}

Key words: Community, Biodiversity, Poverty, Equity, Bangladesh, Baor, CBFM

\section{INTRODUCTION}

Co-management is the "partnership arrangement between government and the local community of resource users, sometimes also connected with agents such as NGOs and research institutions, and other resource stakeholders, to share the responsibility and authority for management of a resource" (FAO 2017). Thus, both resource users and managers work together in a comanagement system. Community based management $(\mathrm{CBM})$ is a related approach but features less involvement of outside administrator and managers. In small-scale fisheries, sector co-management or CBM has been introduced over the past few decades in many countries with some positive outcomes, even though a few negative ones. A increasing number of studies have shown that comanagement has a range of advantages over a command and control approach (Hossain et al. 2007). These include reduction in the cost of administration and regulatory enforcement, greater trust between government and resource users,

*Author for correspondence: <monirulislam153@yahoo.com>

(c) 2018 Zoological Society of Bangladesh DOI: http://dx.doi.org/10.3329/bjz.v46i2.39044 
reduced conflict between resource users, increased compliance with regulations, and raising local and national consciousness of local environmental issues (Constantino et al. 2012).

Bangladesh produces 3.88 million metric tons of fish every year in which aquaculture contributes the most (57\% of the total production) followed by inland waters capture-based fisheries (27\% of total production) affiliating to the $5^{\text {th }}$ and $3^{\text {rd }}$ position in world fish production hierarchy, respectively (FAO 2018, FRSS 2017). Over one third of total fish habitat in Bangladesh is occupied by inland water-bodies, which support some 260 fish species (FRSS 2017).

In Bangladesh, baors or oxbow lakes are one of the important inland water resources, which are created due to the changed course of the rivers. There are more than 600 baors in south-western Bangladesh, covering an area of 5,488 ha, each ranging from 10 to 500 ha. These baors support many of the 260 freshwater fish species, which are declining trend and produce 7,729 metric ton fish annually (FRSS 2017). However, despite relatively small contribution to nationwide fish production 84,000 people are directly and indirectly depend on baors, the vast majority of them are poor (FRSS 2017). In Bangladesh, comanagement in fisheries sector has been introduced from 1990s for managing inland open water fisheries resources such as floodplains, haors (a large depression that has connection with river(s)), oxbow lakes (locally called baors) and wetlands. In some baors co-management has resulted higher fish production due to aquaculture (Thompson et al. 2003, Biswas et al. 2009). Biswas et al. (2009) found that CBM resulted better production, income and net benefit in baor compare to traditional method of management. However, there are debates whether this co-management has really benefited the poor fishers. The impact of CBM on ecosystem and biodiversity is not fully known. It has been indicated in some studies that some issues and barriers may prevail to influence the co-management process (Hasan and Talukder 2004). The management barriers can be natural, technological, economic, social or formal institutional, which are often interrelated and combine to constrain the process (Islam et al. 2014). In Bangladesh studies on baor fisheries focusing on biology, culture system and traditional management system are scanty (Hossain et al. 1999). The barriers to fisheries based adaption has been studied in coastal fisheries of Bangladesh (Islam et al. 2014). However, no such study has been performed for baor co-management. Therefore, the objective of this study is to assess the current status and to identify the barriers of baor fisheries management system in Jessore district, Bangladesh. 


\section{MATERIAL AND METHODS}

The study was performed in a baor named 'Jhapa baor' at Monirampur upazila of Jessore district, Bangladesh. The baor is the largest freshwater body in this region that is the de-functioned part of the river Kapotakkho. Some important characteristics of this baor are listed in the Table 1. The villagers use this water-body for different purposes including fishing, irrigation and domestic needs. Rain is the main water source of the baor, while occasional intrusion of river water also feeds the baor. The selected baor for the study was under the Ministry of Land of the Government of Bangladesh who gives lease to fisher groups for community-based aquaculture. Beside fish culture, this water-body is also used for paddy cultivation, transportation and other activities in the surrounding area. Local poor fishers catch fish and their livelihoods totally depended on the baor. In Jhapa baor water remains almost all the year round but in rainy season the area increases to up to 605 acres. People directly or indirectly dependent on this baor engaged in fish culture, fish marketing, agriculture, transport and other occupation. CBM is practiced for fish culture by an association of 180 local fishers named -Jhapa Matsajibi Somobay Samiti Ltd. In total 600 households are dependent on this baor, part- or full-time, for their livelihoods.

Table 1. Jhapa baor: at a glance (Source: Field observation and statistics, E. 2012)

\begin{tabular}{ll}
\hline Characteristics & Jhapa baor \\
\hline Distance from Monirampur sub-district & $10 \mathrm{~km}$ south-west \\
Name of dependent villages & Mobarakpur, Komolpur, Jhapa, Rajbari and Rampur \\
Total area & 605 acre \\
Dependent population & 3000 \\
Fisheries management system & Community based fisheries management \\
\hline
\end{tabular}

Both quantitative and qualitative methods were applied for primary data collection from the respondents. There are five villages around the Jhapa baor. To identify barriers respondents were selected among the local fishers as well as from other stakeholders who are related to baor resources. These included local leaders, regional fisheries office, NGOs, and other organizations' personnel. The part time fishers who do not pay any money for fishing in the baor are termed as non-lease holders in this study.

Primary data were collected by using 27 face-to-face semi-structured interviews and focus group discussions (FGDs) and key informant interviews between April and November, 2015. A semi-structured questionnaire was designed following De Vaus (2002) and adapted to collect both quantitative and qualitative data from baor dependent fishers. The responses from closed 
questions allowed statistical analysis, whereas the open-ended questions gathered qualitative data eliciting more detail and personal opinions on specific issues.

Secondary data were collected from Upazila Fisheries Offices, Society for social service, various NGOs, District Commissioner Office of Jessore, and Bangladesh Meteorological Department. These data included information about baor management system, geographical and administrative distribution of the commune, types of main economic activities, settlement patterns, types of natural resources, and demographic information of this baor.

The qualitative data gathered by interviews and FGDs were analyzed using the modified grounded theory approach (Strauss and Corbin 1997). Literature review allowed possible predetermined categories (themes) of empirical data such as climate, social, educational, economic parameters before analyzing them (Strauss 1987). During the different steps of analysis, these categories were revised and subdivided based on the themes that arose from the data (grounded theory approach) (Strauss and Corbin 1997). Content analysis technique (Miles and Huberman 1994) was used to analyze the qualitative data before translation. At the later stage of writing, selected quotes were translated into English. Qualitative data analysis consisted of three steps: (i) preparing and organizing the data for analysis, (ii) reducing the data into themes through a process of coding and condensing the codes, and (iii) finally representing the data in table or as part of a discussion (Creswell 2012). After finishing the analysis, the results were checked again with the original transcripts to ensure further reliability. Quantitative data like income were analyzed in Statistical Package for the Social Sciences (SPSS) using descriptive statistics and the means were compared.

Temperature and precipitation data bound within the coordinates of Monirampur upazila $\left(89^{\circ} 05^{\prime} \mathrm{E}-89^{\circ} 21^{\prime} \mathrm{E}\right.$ and $\left.22^{\circ} 57^{\prime} \mathrm{N}-23^{\circ} 05^{\prime} \mathrm{N}\right)$ were collected from University of East Anglia Climatic Research Unit (2017). Data were analyzed using Grid Analysis and Display System (Grads) tool. The seasonal data were modified for creating monthly climatology to calculate yearly anomalies over the time periods. Then the smoothed values for the temperature and precipitation were obtained by filtering time series data. After analyzing temperature and precipitation data, their changes were assessed by fitting a linear trend over the periods of the data availability.

\section{RESULTS AND DISCUSSION}

In Japha baor both aquaculture and capture fisheries are practiced concurrently in which both lease holders and non-lease holders catch fish 
creating both positive and negative impacts. Out of 3000 baor dependent people, only 180 leaseholders paying 4,200,000 Tk./year and are involved in aquaculture. This baor is managed through leasing process, as CBM or comanagement. Others are mainly part-time fishers who only catch non-target fish from the baor during some specific time in a year using some specific gears. The aquaculture species includes mainly major carps such as Labeo rohita (Hamilton 1822), Cyprinus carpio (Linnaeus 1758), Ctenopharyngodon idella (Valenciennes 1844), Hypophthalmichthys molitrix (Valenciennes 1844) and Gibelion catla (Hamilton, 1822). Often supplementary feeds are applied for better growth of these species. Most participants reported that the introduction of aquaculture has resulted in the increased total fish production and more profit for the leaseholders. However, they also reported that due to competition and intervention of aquaculture (e.g., use of fertilizers and feeds) small indigenous fish species have been locally extinct or threatened. The fishes were Channa sp., Puntius sp., Mastacembelus sp., Mystus sp. and Colisa fasciatus.

Barriers to baor fisheries: Analyzing primary and secondary data the study identified a range of barriers to baor fisheries management as shown in Fig. 1.

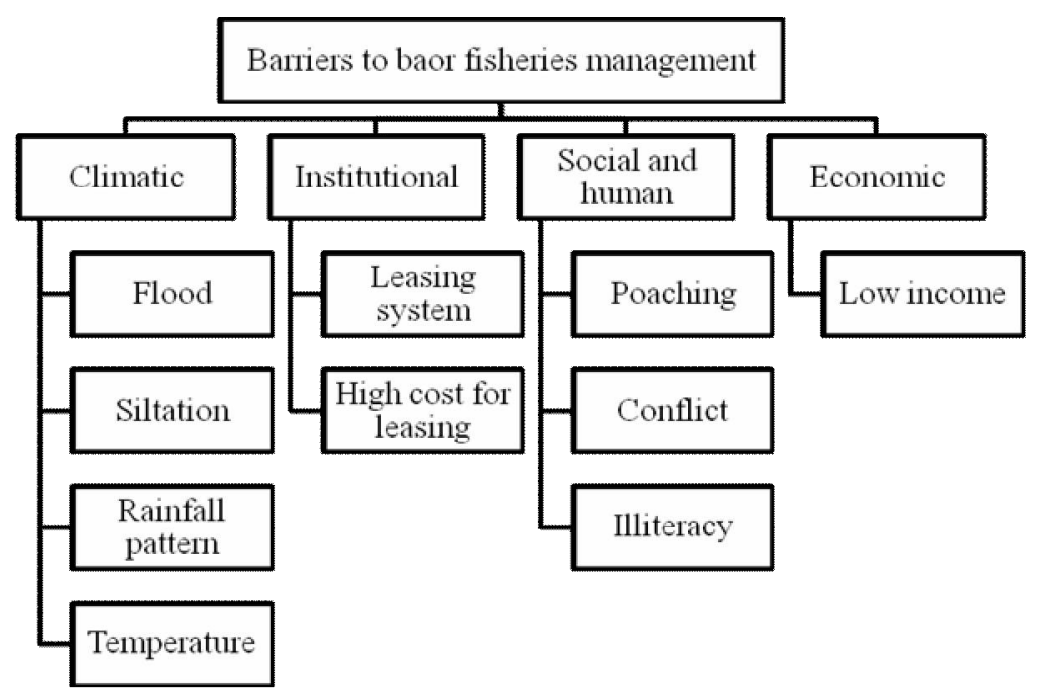

Fig. 1. Barriers to baor fisheries management in Bangladesh.

Climatic barriers: Flood, rainfall, siltation and temperature are critical climatic barriers identified for baor fisheries management (Fig. 1). The various climate related barriers differ in intensity and nature and are related to other type of barriers. 
Among all barriers, flood constraints the most for the baor fisheries management. Siltation, surface run off and construction of dams and bridges are main causes for flood. After the flood in 2000, a large amount of silt deposited in the baors that resulted decreased navigation and water discharge rate through river. Floods have been affecting negatively over the past many years with increasing flood level and severity in 2005, 2008 and 2015. The impacts include inundation, pollution, spread of disease, and damage to fish culture and dependent livelihoods. Fish diseases, fish poaching, conflict with local poor fishers are common phenomenon during flood. Management authority reported that fish mortality has increased due to viral disease, gill rotten diseases after the flood had started.

Analyzing the meteorological data (From 1975 to 2014) of study area reveals that heavy rainfall period is June to August (Fig. 2). Some respondents reported that variation in the amount and starting period of rainfall, to some extent, created problems for baor management. If the drainage capacity of river and the sluice system are good then the rain water can be discharged properly. Monsoon rainfall has increased over the same period (Fig. 3). High rainfall during monsoon together with reduced drainage of surrounding river makes the baor vulnerable to flood during this season. About $20 \%$ fishers reported that flood started from June immediately after the heavy rainfall.

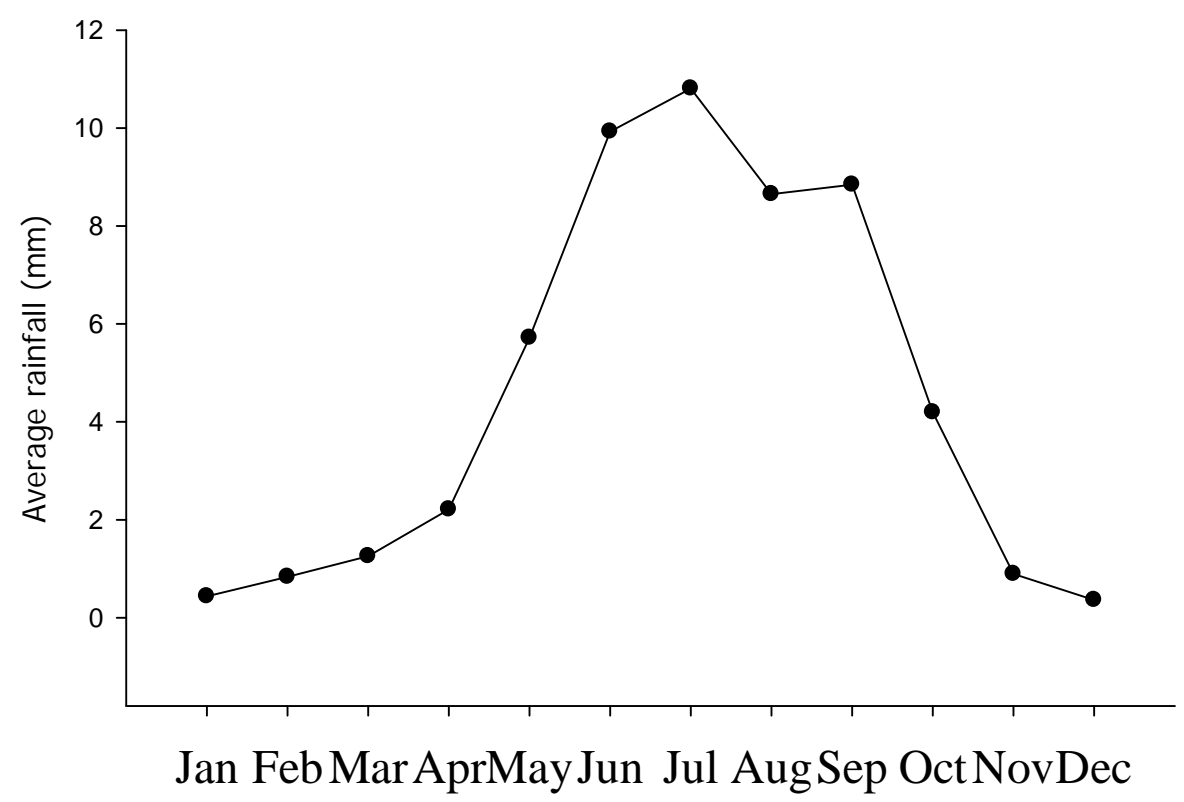

Fig. 2. Annual average rainfall from 1980 to 2014 in the study area, Jessore. Data source: Bangladesh Meteorological Department (2015). 
The analysis of monthly temperature anomaly data of Jessore region indicates that the average temperature in the study area has increased by $0.73^{\circ} \mathrm{C}$ at a rate of $0.0133 /$ year over the period of 1960 to 2015 (Fig. 4). A major portion of the respondent (60\%) commented that there was no effect of temperature on baor fisheries but agreed that temperature is increasing day by day. Some respondents relate mortality of the stocked fish fry with increased temperature. One fisherman and former baor lease holder said: "in recent years increased level of temperature had resulted more death of the fish fry after stocking into the baor."

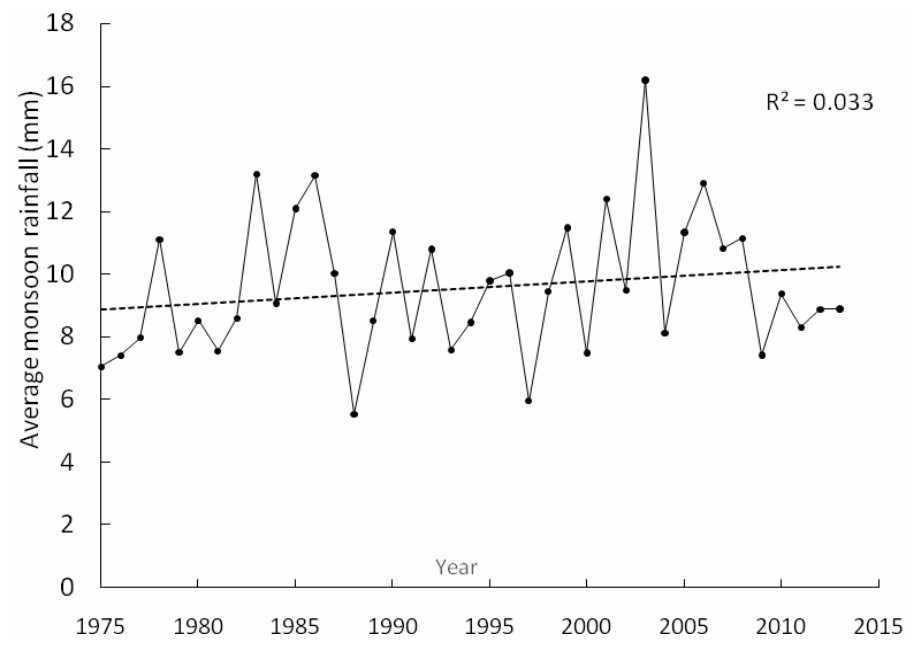

Fig. 3. Monthly average rainfall from 1980 to 2014 in the study area, Jessore. Data source: Bangladesh Meteorological Department (2015); analysed by the authors.

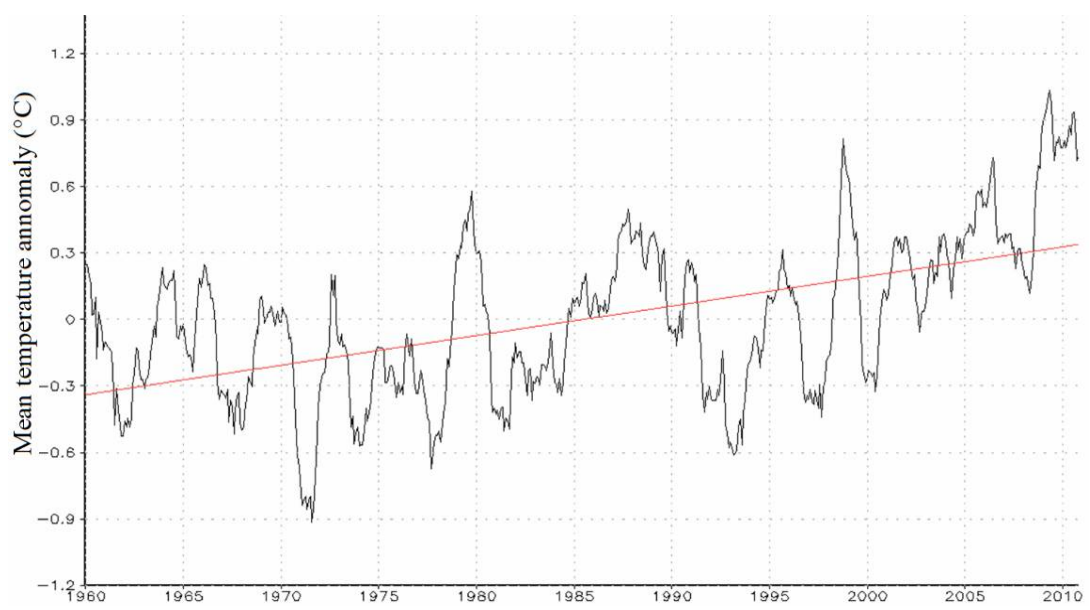

Fig. 4. Annual mean temperature anomaly from 1960 to 2014 in the study area, Jessore. Data source: Bangladesh Meteorological Department (2015). 
Although per year increment of temperature is low but the sudden increase of temperature for a few days can be fatal for young aquatic animals. Seneviratne et al. (2012) projected that climate change results in the increase of extreme temperature events because a small rise in mean temperature can boost the odds of extreme heat and heat waves.

Leasing of baor to public has been practiced since 1900s. In recent times, there were some governmental projects to better manage the baor fisheries resources (Ministry of Land 2009) under the institutional umbrella of Jalmahal Management Policy, 2009. According to this policy, only real fishers can get lease of the baor by creating a fishers association or co-operative that is officially registered. Real fishers are those who catch and sell fish for their livelihoods and living nearest to the baor. The area of the Jalmahal more than 20 acres - like the Japha baor - is leased by the district Jalmahal committee on behalf of Ministry of Land. However, this is co-managed by the fishers' cooperative and the Department of Fisheries (DoF), Ministry of Fisheries and Livestock.

The Jalmahal leasing policy itself restricts many fishers to get the proportional benefit from the baor. In study area, the fishers reported that most of the time local powerful people had convinced the poor fishers to form an association to get the lease.

Most of the financial contribution (more than 80\%) came from the powerful people who are usually not fishers, while other poor fishers (about 165-170) contributed very small amount to the leasing money. These major contributors form the baor management executive committee - a 10 to 15 members committee that takes the decision of managing and running the baor under the overall guidance of the DoF. Most fishers said that the DoF has very poor monitoring system. The decisions taken by the executive committee often favor themselves but disfavor the other leaseholders in catching quota and sharing benefit. This leasing system is depriving the poor fishers in two ways disfavouring the poor lease holders and eliminating the non-lease holders.

Around the Japha baor there are eight fishers' co-operatives consisting of about 380 fishers (excluding their household members) but only one named Jhapa Matsajibi Somoboy Samiti Ltd. or Baor Fishers Cooperative Association Limited managed to get the lease. These non-lease holders are very poor and some of their cooperatives are not officially registered to the government. The lease holders have access to both aquaculture and capture fisheries. Whereas the non-lease holders only has access to capture fisheries. These processes create conflict between lease and non-lease holders as said by one in three fishers. 
One of the reasons for involvement of the powerful and rich non-fishers is the high rate of taking lease. In 2006, the government increased the leasing money of this baor form 450,000 Tk to 4,200,000 Tk. Poor fishers had no ability to provide this money to take lease. It was a chance for the rich, powerful people (sometimes politician) to take the lease. High leasing money also induces the lease holders to restrict the non-lease holder part-time fishers from fishing in order to maximize the profit by catching more capture fishes. The lease holder not only impose one month total fishing ban during stocking of aquaculture species and but also impose gear ban - most nets are banned in most areas of the baor.

The participants also reported that biodiversity and natural balance of baor also hampered due to high leasing money. As leasing money was high, stakeholders tried to culture fast growing fish in high density which has negatively affected the indigenous fish species. This densely stocking of fast growing cultured fish competed with indigenous fish for shelter and food. To facilitate the aquaculture often artificial foods suitable mainly for culture fish were supplied. This impact negatively on the natural food chain, thus creating problems for the small indigenous species. These conditions paved the way to extinction of indigenous fish species from baor.

Main social and human barriers to baor fisheries management are poaching, conflict and illiteracy (Fig. 2).

Poaching of aquaculture species by the non-lease holder fishers was identified by the baor executive committee as a problem. If any of these species is trapped in non-lease holders' gear they should release it. But the executive committee found that sometimes they do not release the fish. Besides some nonlease holders use prohibited net. The non-lease holder may suffer from lack of ownership of the baor that may influence them to disobey the regulations. Yamamoto and Nickerson (1998) also worked on Phangnga bay, Thailand and found that ownership of waterbody encourages the fishers to manage resources in a sustainable way.

In the study area low literacy rate of baor management authority and both lease and non-lease holders are responsible for poor baor management. About $35 \%$ fishers of all types were illiterate and $40 \%$ had only primary level education. Most of the fishers (80\%) of both lease and non-lease holders reported that they were deprived by the baor management executive committee because of lack of education. They also lacked knowledge and skills on proper fish stocking techniques which resulted in higher post stocking mortality.

The main economic barrier was the low income of the baor fishers that led their low livelihood conditions. Monthly average income of a fisher household in 
Jhapa baor area was 8,930 Tk. which was lower than the national average, 11,479 Tk. (BBS 2012). Due to the low income fishers' communities were not able to take lease of the baor without the support of others. More than $80 \%$ fisher households lived from hands to mouth and $60 \%$ had no agricultural land. If they could not catch fish or had no work they had to borrow money from others.

To sum, this study found both positive and negative impacts of baor fisheries co-management. It has resulted increased fish production and income for some people. On the other hand, it has reduced access to many poor fishers dwindling their livelihood conditions. The aquaculture intervention has also resulted in the declination of aquatic biodiversity in the baor. This study thus does not fully agree with Jahan et al. (2001) and some other studies that community based management have welfare impact on society, at its current form. The barriers to baor management identified in this study have nonetheless created the points of intervention to overcome the barriers.

\section{CONCLUSION}

This study assesses the present status and obstacles to an oxbow lake fisheries of Bangladesh that is managed by community-based or co-management approach. Using both primary and secondary data this study has found that although fish production has increased, fish biodiversity and access of poor fishers have decreased to baor due to a range of climatic, institutional, social and economic barriers. Particularly, unfair leasing system, poor monitoring by government and lower levels of income and education accompanied by floods, changes in the timing of rainfall and higher temperature create barriers.

To overcome the barriers a fair leasing system involving the poor fishers need to be ensured with reduction of leasing price. Poor fishers need to be educated and provided with low interest financial assistance to divert their livelihoods. Although the fish production of the baor increases but indigenous fish species has decreased. Fish sanctuary need to be built up to ensure breeding ground of indigenous fish to protect them from extinction. More broadly ecosystem-based management of baors can help recover biodiversity and secure production simultaneously.

Acknowledgements: This project is funded by the Ministry of Science and Technology, Government of Bangladesh, 2014-2015. Grant No. BS-84. Authors are thankful to Mr. Makidul Islam Khan for his help in preparing a few Figures. 


\section{LITERATURE CITED}

BBS (Bangladesh Bureau of Statistics) 2012. Statistical yearbook of Bangladesh. Ministry of Planning, Govt. of People's Republic of Bangladesh, Dhaka, Bangladesh.

BISWAS, M. M. R., ISLAM, M. F., RAHMAN, M. M., KAWSAR, M. and BARMAN, S. K. 2009. Fisheries management scenarios of two baors in the district of Chuadanga, Bangladesh JIDS. 3(5): 11-15.

CONSTANTINO, P.D., CARlos, H., RAMAlho, E., ROSTANT, L., MARINElli, C., TEleS, D. and VALSECCHI, J. 2012. Empowering local people through community based resource monitoring: a comparison of Brazil and Namibia. Ecology and Society 17(4): 22.

CRESWELL, J.W. 2012. Qualitative inquiry and research design: Choosing among five approaches. Sage publications, Thousand Oaks, California, United States. 448 p.

DE VAUS, D.A. 2002. Surveys in social research (fifth edition), Routledge, London. 397 p.

FAO. 2018. The State of World Fisheries and Aquaculture 2018 - Meeting the sustainable development goals. Rome. Licence: CC BY-NC-SA 3.0 IGO.

FAO. 2017. Co-management. Retrieved from http://www.fao.org/fishery/topic/16625/en accessed on 30 Sept 2017.

FRSS. 2017. Yearbook of Fisheries Statistics of Bangladesh. Fisheries Resources Survey System (FRSS), Department of Fisheries, Bangladesh 33: 116.

HASAN, M.R. and TALUKDER, M.M.R. 2004. Development of management strategies for culture based fisheries in Oxbow lakes in Bangladesh. Bangladesh Journal of Fisheries (Special issue), 27: 57-58.

HOSSAIN, M.K., NASER, M.N. and LATIFA, G.A. 2007. Some aspects of beel fisheries under a privately owned community based fisheries management at Pocha Boalia, Raipura, Narsingdi. Bangladesh J. Zool. 35(2): 397-401.

HOSSAIN, M. S., EHSHAN, M.A. and MAZID, M.A. 1999. Fish biodiversity study of three floodplains in Bangladesh. In: Sustainable Inland Fisheries Management in Bangladesh. ICLARM Conference Proceedings. 5: 229-233 pp.

ISLAM, M. M., SALLU, S., HUBACEK, K. and PAAVOLA, J. 2014. Limits and barriers to adaptation to climate variability and change in Bangladeshi coastal fishing communities. Marine Policy 43: 208-216.

JAHAN, K.M.E., ABDULLAH, N.M.R. and VISWANATHAN, K.K. 2001. Welfare Impacts of Fisheries Co-management System at Oxbow Lakes in Bangladesh. Proceedings of 10th International Institute of Fisheries Economics and Trade (IIFET) Conference, July 10-14, 2000, Corvallis, Oregon, U.S.A.

MILES, M. B. and HUBERMAN, A.M. 1984. Qualitative data analysis: A sourcebook of new methods. Sage Publications, Thousand Oaks, California, United States. 263 pp.

SENEVIRATNE, S.I., NICHOLlS, N., EASTERLING, D., GOODESS, C.M., KANAE, S., KOSSIN and J. REICHSTEIN, M. 2012. Changes in climate extremes and their impacts on the natural physical environment. In: C.B. Field, V. Barros, T.F. Stocker, D. Qin, D.J. Dokken, K.L. Ebi, M.D. Mastrandrea, K.J. Mach, G.-K. Plattner, S.K. Allen, M. Tignor, P.M. Midgley (Eds.). IPCC WGI/WGII Special Report on Managing the Risks of Extreme Events and Disasters to Advance Climate Change Adaptation (SREX). Cambridge Univ. Press, The Edinburgh Building, Shaftesbury Road, Cambridge CB2 8RU ENGLAND. 109-230 pp.

STRAUSS, A. 1987. Qualitative Analysis. Cambridge University Press, New York. 319 p. 
STRAUSS, A. and CORBIN, J.M. 1997. Grounded theory in practice. Sage publications, Thousand Oaks, California, United States. 280 pp.

THOMPSON, P. M., SULTANA, P. and ISLAM, N. 2003. Lessons from community based management of floodplain fisheries in Bangladesh. J. Environmental Management 69(3): 307-321.

YAMAMOTO, T. and NICKERSON, J.D. 1998. Community-based fisheries management. Communitybased Fisheries Management in Phang-nga Bay, Thailand, 209-227 pp.

(Manuscript received on 10 August, 2018; revised on 18 September, 2018) 